University of Nebraska - Lincoln

DigitalCommons@University of Nebraska - Lincoln

July 2006

\title{
The Missing Court of Claims Report: Is Letitia Humphreys Court of Claims Report 42?
}

Charles D. Bernholz

University of Nebraska-Lincoln, cbernholz2@unl.edu

William R. Ellis Jr.

National Archives and Records Administration

Follow this and additional works at: https://digitalcommons.unl.edu/libraryscience

Part of the Library and Information Science Commons

Bernholz, Charles D. and Ellis, William R. Jr., "The Missing Court of Claims Report: Is Letitia Humphreys Court of Claims Report 42?" (2006). Faculty Publications, UNL Libraries. 38.

https://digitalcommons.unl.edu/libraryscience/38

This Article is brought to you for free and open access by the Libraries at University of Nebraska-Lincoln at DigitalCommons@University of Nebraska - Lincoln. It has been accepted for inclusion in Faculty Publications, UNL Libraries by an authorized administrator of DigitalCommons@University of Nebraska - Lincoln. 


\title{
The Missing Court of Claims Report: Is Letitia Humphreys Court of Claims Report 42?
}

\author{
Charles D. Bernholz ${ }^{\mathrm{a}, *}$, William R. Ellis Jr., ${ }^{\mathrm{b}, 1}$ \\ ${ }^{a}$ Love Memorial Library, University of Nebraska, Lincoln, NE 68588, USA \\ ${ }^{\mathrm{b}}$ Old Military and Civil Records, Textual Archives Services Division, National Archives and Records \\ Administration, 700 Pennsylvania Avenue, NW, Washington, DC 20408-0001, USA
}

Available online 26 May 2006

\begin{abstract}
Between the years 1855 and 1863, the opinions or "reports" of the United States Court of Claims were delivered to the House of Representatives for final consideration. In total, 296 cases were conveyed, but in the process, Report 42 was lost and, according to indexes of such documents, "never received by [the] House."

This article cites examined records of the Court of Claims, from both the United States Congressional Serial Set and original documents now in the National Archives, which support the contention that there was a completed opinion for Court of Claims Report 42 that was lost sometime during its transfer between the Court and the House.

This 150-year-old case - Letitia Humphreys, Administratrix of Andrew Atkinson - was one in a long list of judicial proceedings, involving over 100 claimants, that resulted from the 1812 invasion of Florida by the United States, and that concerned the payment of interest to those compensated under the last clause of the ninth article of the 1819 Treaty of Amity, Settlement, and Limits, Between the United States of America and His Catholic Majesty. These Florida petitions were examples of early claims actions against the federal government, in many cases after decades of inaction.
\end{abstract}

(C) 2006 Elsevier Inc. All rights reserved.

\footnotetext{
* Corresponding author. Fax: +1 4024725131.

E-mail addresses: cbernholz2@unl.edu (C.D. Bernholz), robert.ellis@nara.gov (W.R. Ellis).

${ }^{1}$ Fax: +1 2022196273 .
} 
The Court of Claims was created in $1855^{1}$ and was formed in response to the ever-growing number of claim petitions that demanded far more attention than Congress could afford. Initially, claims following Independence were handled by the Treasury Department, as authorized by Congress, and distinctive administrative groups handled special claims cases like those following the War of 1812. This process led to a larger participation by Congress itself, with the creation of claims committees that assured some insulation from the constitutional questions that plagued such claims. Specifically, there were concerns that allocating claim petitions to a forum other than to Congress would violate the First Amendment right that citizens may "petition the government for a redress of grievance." Further, Article I, $\S 9$ of the Constitution required that "no money shall be drawn from the Treasury, but in consequence of appropriations made by law," and so Congressional supervision of claims payments was considered appropriate. ${ }^{3}$

However, the burden grew over time. ${ }^{4}$ Congress became progressively more concerned that "[n]o counsel appeared to watch and defend the interest of the Government," and that, with their own propensity to find it "more convenient and more safe not to act at all upon those claims which called for much investigation, especially when the amounts involved seemed large," petitions carried on for years, sliding from one Congress and one standing committee to the next. The creation of the Court of Claims in 1855 addressed some of these issues.

Of particular interest within this jurisdiction are the early, carry-over cases that populated the Court's calendar. There was an immediate opportunity to respond to these petitions. The main case opinions for these first 295 proceedings ${ }^{6}$ were published in House of Representatives Court of Claims volumes as part of the communications between the Court and Congress. The United States Congressional Serial Set holds these cases in a suite of eighteen volumes, ${ }^{7}$ with the cases sequentially numbered.

Further, it is worthy to note the development of reports sent to the Senate that paralleled the action of the Court and its communications with the House. The Senate Report Committee of Claims, to which was referred "An Act making appropriations for the payment of certain claims," together with opinions of the Court of Claims in the cases of Samuel P. Todd, John Shaw, and Isaac Beaugrand ${ }^{8}$ was used to convey the Court's findings for the three initial Court of Claims cases, Samuel P. Todd, ${ }^{9}$ Isadore D. Beaugrand, ${ }^{10}$ and John Shaw. ${ }^{11}$ As an indication of the delay that some of these petitions endured, Todd concerned interest on money due since the period 1812 to 1815 . The Court concluded that only the original amount was due Todd, without interest, although "interest may be added if Congress should see fit to allow it." 12 Beaugrand was a case involving an Ohio volunteer in the war with Mexico who petitioned for, and won a judgment, of $\$ 162.81$ plus interest. ${ }^{13}$ Shaw requested $\$ 1000$, and interest, for serving as an interpreter to translate Winnebago into French and English during the 1828 trial of nine Indians charged with murder. The principal was awarded, but interest was not. $^{14}$

One of the ways to locate these early cases is to examine checklists or indexes that focus upon documents of that era, but it appears that there is one Court of Claims Report that is missing. The Tables of and Annotated Index to the Congressional Series of United States 
Public Documents ${ }^{15}$ have, under the heading Reports to the House of Representatives, the notation "No. 42 never received by House." The Checklist of United States Public Documents, 1789-1909 ${ }^{16}$ declares the same finding. More recently, this absence is shown by the "[Blank]" title used for this Court of Claims Report number in the CIS US Serial Set Index, ${ }^{17}$ and Imholtz included "CC.rp.42" as one of the many unused Document and Report numbers in the Serial Set. ${ }^{18}$ Inspection - either by hand or through the Readex United States Congressional Serial Set database ${ }^{19}$ - of Serial Set volume 872 reveals, in this court opinion series, cases between Report $27^{20}$ and $41,{ }^{21}$ whereas Serial Set volume number 915 lists cases for Report $43^{22}$ through $81 .^{23}$ The Index of the latter Serial Set volume begins with the statement: "Note: The report No. 42 of the Court of Claims has never been communicated to the House of Representatives." ${ }^{24}$ This was the only missing Congressional Court of Claims Report for cases delivered directly to the House of Representatives before the onset of the Court of Claims Reports court reporter.

A fundamental difficulty that the Court experienced at that time was its status as an advisory, and not as a judicial, forum. Its task was to advise Congress, which in turn approved or disapproved the proposal suggested by the Court. The true operational purpose of the Court was in limbo until 1863 when a more judicial model was developed. ${ }^{25}$

The delivery of the missing Court of Claims Report 42 would have occurred years before these procedural adjustments, and so would have been administered under an advisory climate. As additional demonstrations of the atmosphere of the Court at that time - besides the conclusion in Court of Claims Report 1 for the Todd case that "interest may be added if Congress should see fit to allow it" ${ }^{26}$ - the opinion in Report 41 ends with the proposal that "[w]e shall report to Congress a bill in favor of the petitioner for four thousand eight hundred dollars," 27 whereas in Report 43, the Court pronounced "[w]e are, therefore, of the opinion that the facts set forth in the petition of the claimant do not furnish any ground for relief as to this claim. No order will be made authorizing the taking of testimony in this case." ${ }^{28}$ In other words, the opinions for the petitions adjudicated by the Court contained only recommendations to Congress.

Samuel H. Huntington, the Chief Clerk of the Court of Claims throughout all these early cases, tendered this Swain and this Boyd case on 1 August 1856 and 19 January 1857, respectively. ${ }^{29}$ As confirmed by a table of the first 198 cases returned to the House by the Court of Claims, groups of opinions were frequently transmitted to the House on the same date, and therefore the opinion submission sequence was in almost perfect chronological order. $^{30}$ The Swain case (Report 41), on 1 August 1856, followed a group submission to the House of over twenty cases that had been convened at the end of June. A break in the Court's calendar delayed the decision on the Boyd, or Report 43, case until the beginning of 1857. These two date boundaries, in conjunction with the almost faithful correspondence of the ordinal Report number and submission date, would suggest that the case opinion, if any, for missing Report 42, would have left the Court near the beginning of August 1856.

Such a case exists. It was reported as Letitia Humphreys, Adm'x vs. the United States. ${ }^{31}$ This citation appeared in an 1857 Senate Miscellaneous Document that declared "The Court of Claims submitted the following report. The honorable the Senate and House of 
Representatives of the United States in Congress assembled: The Court of Claims respectfully presents the following documents as the report in the case of Letitia Humphreys, Adm'x vs. the United States. ${ }^{32}$ It presented to the House the petition of Letitia Humphreys, brought to the Court of Claims as administratrix de bonis non for the estate of her father, Andrew Atkinson, and the syntax of the introduction used in this document is virtually identical to that used in Court of Claims Reports with nearby Report numbers.

The list of documents presented for this petition consisted of eight elements, including an opinion delivered by Judge Isaac Newton Blackford; a dissent by Judge George Parker Scarburgh; and an opinion and a dissent on rehearing by Chief Justice John James Gilchrist and by Scarburgh. ${ }^{33}$ It was signed and dated by Samuel H. Huntington, the Chief Clerk, on 1 August 1856, that is, on the same date as the forty-first or Swain Court of Claims Report was presented. Further, the subheading to the initial caption of Humphreys - "In the Senate of the United States" - indicates the dates upon which actions were taken on this case: "August 1, 1856 - Read and referred to the Committee of Claims; December 18, 1857 Referred to the Committee of Claims." ${ }^{34}$ The Congressional Globe, on the first date, confirmed that "[t]he President pro tempore laid before the Senate a report of the Court of Claims, made in pursuance of the law, of the opinion of that court on the claim of Letitia Humphreys, administratrix of Andrew Atkinson, deceased, and of the decision of the court in favor of the claim of Mary Reeside, executrix of the will of James Reeside, accompanied by a bill for the relief of Mary Reeside, executrix of James Reeside; which, on the motion of Mr. Brodhead, were referred to the Committee on Claims." ${ }^{35}$ An identical statement was entered for the same date in the Journal of the Senate. The Reeside case ${ }^{36}$ was delivered as Court of Claims Report 26, dated 22 July 1856. Thus, both a numbered Court of Claims Report - Reeside - and the absent Humphreys case were submitted to the Senate Committee of Claims on the same date.

The Humphreys inquiry concerned the payment of interest to those compensated under the last clause of the ninth Article of the 1819 treaty with Spain. ${ }^{37}$ The relevant text reads: "The United States will cause satisfaction to be made to injuries, if any, which, by process of law, shall be established to have been suffered by the Spanish officers and individual Spanish inhabitants, by the late operations of the American army in Florida." ${ }^{38}$

Letitia Humphreys' father, Andrew Atkinson, was during the years 1812 and 1813 a Spanish subject living in Spanish-controlled East Florida. A biography of Humphreys' son ${ }^{39}$ - General Andrew Atkinson Humphreys - contains a rich source of genealogical data for both families. Andrew Atkinson and his wife immigrated to the United States in about 1785 and, after living in Georgia for a period, purchased a plantation north of today's Jacksonville. Letitia was born in 1786, and she married Samuel Humphreys in the first decade of the nineteenth century. Their son Andrew was born in 1810 .

As a planter, Atkinson sustained damages following the invasion of this area by the United States. ${ }^{40}$ His administratrix in 1834, Mrs. Susan Murphy, filed an 1817 claim for his estate totaling $\$ 11,294 .{ }^{41}$ In 1839 , a judge in East Florida declared that the estate should receive $\$ 3,800$, plus 5 percent interest per year from 1813 , and conveyed this recommendation to the Secretary of the Treasury for payment. ${ }^{42}$ The Secretary, Levi Woodbury, refused to honor this 
proposal and in November 1839 ordered payment of only $\$ 2,300$ to satisfy the claim. ${ }^{43}$ In compliance with a position that he had initiated for such claims in $1836,{ }^{44}$ he did not allow interest on the amount claimed. In 1852, a successful attempt was made to recover from the Treasury the remaining $\$ 1,500$, but still no interest was conveyed. ${ }^{45}$ Letitia Humphreys, in July 1855, filed a petition in the Court of Claims for this interest.

A note within this document is significant because it remarks "[ $\mathrm{t}]$ he claim of Andrew Atkinson is one of a class which will be found fully set forth in a report of the Secretary of the Treasury to the Senate, being Ex. Doc. No. 82, 1st session 33d Congress. For the action of the Congress on said claims see the report of the Judiciary Committee of the House of Representatives, being report No. 22, 2d session 33d Congress, in the case of Robert Harrison. See also report of the Judiciary Committee of the Senate, dated 24th day of February, 1851, in the case of John Forbes." 46 These references are to the report entitled Robert Harrison and Others ${ }^{47}$ and to one on Forbes. ${ }^{48}$

Further, the actual brief from the Court of Claims was reproduced in the Letitia Humphreys, Adm'x vs. the United States document, including a reference to the 1851 United States Supreme Court case United States vs. Ferreira that questioned the Florida district court's decision to honor Ferreira's similar claim; the Supreme Court dismissed that case "for want of jurisdiction" (54 U.S. 40, 52). ${ }^{49}$ The Humphreys' brief included these findings under its contentions when it declared that "[ $t]$ he measure of damages adopted by the Florida judges, in this and other cases of the class, to wit, the proved value of the property at the time of its loss or destruction, with interest, at the legal rate of the country, as a satisfaction for the further damage occasioned by the loss of the annual use and fruits of such property, or of its value, is the most mitigated measure, recognized by the law of nations, as a satisfaction for such injuries." ${ }^{50}$ Charles E. Sherman, attorney for many Florida claims petitioners, signed the brief as one of two counsels for the claimant. ${ }^{51}$ Pages 73 through 91 contain the brief "On the petition of Letitia Humphreys," submitted by the United States Solicitor of the Court of Claims, Montgomery Blair. ${ }^{52}$

Judge Blackford concluded in Humphreys that the Atkinson and subsequent claims for compensation, arising from the parameters of the ninth article of the treaty with Spain, had been handled appropriately at both the district court level as well as by the Secretary of the Treasury. As a result, Letitia Humphreys' claim acquired "no grounds for relief." Judge Scarburgh, in a dissent three times the length of Blackford's opinion, considered that "the United States are bound by the faith of treaties" and so should compensate Humphreys. ${ }^{54}$ A rehearing was requested, but denied by Chief Justice Gilchrist. Scarburgh dissented again, and the case was closed.

There is corroborating evidence that Letitia Humphreys was a comparable Court of Claims case. Two numbered Court of Claims cases, printed in the same Serial Set volume as Letitia Humphreys, Adm'x vs. the United States, were similarly sent to the Senate and published as Miscellaneous Documents. David Myerle vs. the United States ${ }^{55}$ and Eliza Schaffer vs. the United States $^{56}$ are directly linked to Court of Claims Report $81^{57}$ and to Report $114,{ }^{58}$ respectively. The Index for that Serial Set volume has three individual entries for a "Report of the Court of Claims in the case of David Myerle"; for a "Report of the Court of Claims in the 
case of Letitia Humphreys"; and for a "Report of the Court of Claims in the case of Eliza Shaffer." 59

Further, specific Court of Claims actions related to the Humphreys question may be noted in the settlement of the petition of Robert Harrison. Two Congressmen from Florida submitted to their respective chamber the memorial of Charles E. Sherman, counsel for Harrison, Humphreys, and others. On 26 July 1854, Senator Stephen Russell Mallory did so before the Senate. ${ }^{60}$ This was followed in the House on 31 July by the presentation of Representative Augustus Emmett Maxwell. The Maxwell request "was referred to the Committee on the Judiciary" 61 and the result of this appeal was reported to the House on 26 January 1855 by Frederick Perry Stanton, Representative from Tennessee. ${ }^{62}$

Thus, the question of interest payments in cases concerning Article 9 of the 1819 treaty with Spain, and under which Harrison and Humphreys were to be classed, was established well before the beginning of August 1856 when Court of Claims Report 42 would have been sequentially reported. ${ }^{63}$ This indeed was confirmed when Harrison and Humphreys were linked through a citation in the Journal of the Senate on 12 August 1856 that stated that Senator David Levy Yulee (Florida) presented the memorial of Harrison "which was referred to the Committee of Claims," and for similar action for Humphreys "praying that the decision of the Court of Claims on her claim ... may be taken as part of her memorial and referred to that court; which was referred to the Committee on Claims." 64

The Harrison file, now at the National Archives and Records Administration, ${ }^{65}$ contains an unsigned note, apparently from Chief Justice Gilchrist, in response to Harrison's petition. The note states: "[ $\mathrm{t}]$ he question is the same as that heretofore presented in the case of Letitia Humphreys and decided upon by the Court. The opinions heretofore delivered by Mr. Justice Blackford and myself (i.e., Chief Justice Gilchrist) in that case sufficiently state the grounds on which that decision was made" (emphasis added). ${ }^{66}$

Harrison's case was subsequently returned as Court of Claims Report $127 .{ }^{67}$ In presenting the Court's findings, a Senate report ${ }^{68}$ followed the format of the equivalent Humphreys record. It included among its documents the briefs and arguments, as well as the opinion and dissent, from the Humphreys proceedings. The caption heading from Humphreys "December 18, 1857-Referred to the Committee of Claims" - was reproduced as a caption heading in this Harrison report.

The Senate Document for Letitia Humphreys, Adm'x vs. the United States was not a unique publication. It was part of a sequence of documents sent to the Senate that began with the tripartite report on Todd, Beaugrand, and Shaw. Thus, the early model was sustained into later cases including, it would appear, for Humphreys. Searching the Serial Set for documents linked to each petitioner's name for the first 50 numbered Court of Claims cases reveals that, for all but two cases, there is a consistent pattern of a corresponding Senate document relating to each claims case. ${ }^{69}$ Further, one of the Court's docket books, now housed at the National Archives and Records Administration, contains on the same page chronological data for these two Cox and Emery cases and for the Letitia Humphreys petition. The Cox, Emery, and Humphreys docket numbers are 41, 42, and 44. Docket number 43 was assigned to the case of Benjamin H. Springer. ${ }^{70}$ 
With regard to Humphreys, this same docket indicator is reproduced as the heading "In the Court of Claims-No. 44" (emphasis added) in the text of the brief submitted by the United States Solicitor, Montgomery Blair. This brief is part of the Letitia Humphreys, Adm'x vs. the United States Senate Miscellaneous Document. The docket page also indicates that, on 18 July 1855, there was a motion "by claimant's counsel" for materials "from the Treasury Department to be used in the trial of this case." An additional page presents the chronology of the case: "Oct. 13th 1855, claimant's brief filed, Oct. 15, 1855, Solicitors brief filed, 27th Oct. argument commenced, Nov. 9, 1855, argument concluded and case submitted, April 29, 1856, order to take testimony refused, April 30, 1856, motion for new trial argued by A. Pike, new petition filed, May 30., argument concluded, questions submitted-July 101856 , reported to Congress" (emphasis added).

The 10 July 1856 report date is different from Chief Clerk Samuel Huntington's 1 August 1856 submission date contained in the Letitia Humphreys, Adm'x vs. the United States Senate Miscellaneous Document. The docket notations of the Congressional report dates match those of Huntington in each of the Cox, Emery, and Springer cases before the Court, but this disparity between the Humphreys docket date entry and the submission date in the Senate Miscellaneous Document may signal one reason why the Humphreys report never reached the House of Representatives: 1 August 1856 was a Friday, and perhaps the very last day of the Court's term for $1856 .^{71}$

Follow-up analyses ${ }^{72}$ demonstrated the class case status of the past interest problem. The 1860 assessment was a reexamination of this issue and "reached the same conclusion at which this committee arrived the first session of the last Congress," "73 that is, as reported in the 1858 Committee report. The 1859 House report incorporated the findings and the text of the 1858 Senate study, and concluded that interest should be paid on such claims "as a matter of course, and as a necessary legal consequence of the admitted liability to pay the value of the destroyed property. It is as much a portion of the legal damages as the value of the property itself." 74 An attached "Minority Report" cited Judge Blackford's opinion to withhold relief in the Harrison Court of Claims case as evidence that all these petitions should be rejected finally: "Neither the decisions of courts, nor of committees, nor of Congresses, if adverse to them, seem to be considered as final and conclusive. The principle of stare decisis might well be applied to claims like these, which have been so often acted upon and so repeatedly rejected." $" 75$

However, the 1874 report provides additional evidence that the Court had adjudicated the Humphreys' petition. This House of Representatives document commented again upon Article 9 of the treaty with Spain and its application to the class of cases that were consolidated under Harrison's name. In this analysis, the Committee on Foreign Affairs spoke to the issue of the petitioners' memorial and concluded that "[y]our committee, therefore, without entering into a discussion of the propriety or justice of the rule of the Treasury upon which the disallowance of interest was based, or upon recent international decisions bearing upon the subject, but looking at these cases in the light of precedent and law, would report that no legislation is required therein, and would ask that the committee be discharged from the further consideration of the subject." ${ }^{, 76}$ To support this decision, the 
committee remarked in a sentence on page 3 that " $[\mathrm{t}]$ wo of these cases have been before the Court of Claims, Robert Harrison vs. United States, and Letitia Humphreys vs. United States..." (emphasis added).

The later Court of Claims Report 180, Alexander M. Cumming, ${ }^{77}$ had a companion Senate Miscellaneous Document ${ }^{78}$ reporting the proceedings of the Court. The text of that latter item included the remark by the Assistant Solicitor of the Court of Claims, Daniel Ratcliffe: "See ... also the decision of this court in the cases of Letitia Humphreys vs. The United States, Thomas vs. The United States, and Roberts vs. The United States." "79 A subsequent Court of Claims Report, for the petition of the State of Alabama, ${ }^{80}$ was documented in the Senate in the same manner and in that message Solicitor Montgomery Blair explained that, in Alabama, the "case involves only the question of interest, and is the same question decided in Todd's case, and which was discussed in my brief in the Florida claim of Letitia Humphreys."

Later digests, configured to accumulate early Court of Claims proceedings, note the Humphreys case. The United States Court of Claims Digest ${ }^{82}$ lists the case as Humphreys ' $A d m$ 'x v. U.S. but provides no suit citation, as would be expected for the early cases that were conveyed only through reports to the House of Representatives. The results of the petition were used in this summary to provide over two dozen case précis for the subject area sections "Arbitration and Awards," "Treaties," and "United States." These notations point to entries in Devereux's Court of Claims: Reports and Digest of Opinions Delivered Since the Organization of the Court ${ }^{83}$ that collated the results of the earliest cases adjudicated by the Court of Claims. In these comments, there are remarks about the advisory, as opposed to the judicial, status of the judges of the lower courts in Florida; the expansion, through the Act in 1834, to provide for damages caused in 1812 and 1813, that is, in the exact years that Letitia Humphreys' father sustained those brought before the Court; the finality of the decision made by the Secretary of the Treasury; and the role of Congress in executing satisfactorily the political stipulations of Article 9 of the treaty with Spain. Comments from the Humphreys opinion, delivered by Judge Blackford, are especially numerous in Devereux's "Treaties: Treaty of 1819 with Spain" section. Sixteen of the 18 listed judicial points are from that case before the Court.

The main consequence, for this analysis, is the very existence of these proceedings within these compilations and the demonstration, through Devereux's compendium to inform future legal research, that the Humphreys petition was heard and adjudicated by the Court of Claims, and that the opinion contained useful findings. It is especially noteworthy that Devereux included the actual Letitia Humphreys, Adm'x opinion ${ }^{84}$ by Judge Blackford, as part of a suite of nine "leading cases" before the Court of Claims: "the points decided are of immediate practical importance to a large class of claimants." 85 He identified Letitia Humphreys, Adm'x, along with Robert Roberts, as cases "adverse to claims of interest upon Florida adjudications or disturbing decisions of the Commissioners, under the Treaty of 1819 with Spain." 86

The absence of a specific document format for the House of Representatives, therefore, did not pre-empt its use as a relevant, model case for the Florida claims question. 
In summary, there are a number of observations that would support the contention that the petition filed by Letitia Humphreys should have been presented to the House of Representatives as Court of Claims Report 42:

- the presence of entries for Letitia Humphreys, David Myerle, and Eliza Shaffer in the Index of Miscellaneous Documents of the Senate of the United States ${ }^{87}$ under the identical document title of "Report of the Court of Claims in the case of. ..";

- the inclusion of the full text of each of these three Court of Claims proceedings within the same Senate-specific Serial Set volume, and under the case names of Letitia Humphreys, Adm'x vs. the United States, David Myerle vs. the United States, and Eliza Shaffer vs. the United States;

- the identical date for the "read and referred" reference in Humphreys and for the Report submission of Court of Claims Report 41, Isaac Swain;

- the use of Humphreys as a citation to an adjudicated Court of Claims petition, by both the Solicitor of the Court in State of Alabama vs. the United States, ${ }^{88}$ and the Assistant Solicitor in Alexander M. Cumming vs. United States $;^{89}$

- the consistent use of Humphreys as support in the petition of Court of Claims Report 127, Robert Harrison, ${ }^{90}$ and in numerous other considerations of the Article 9 issue ${ }^{91}$

- the use, in Devereux's Court of Claims: Reports and Digest of Opinions Delivered Since the Organization of the Court, of Letitia Humphreys, Adm'x as a key exemplar of early Florida claims cases, and of its notation as both a "leading case" and one which might furnish "immediate practical importance to a large class of claimants";

- Judge Scarburgh's use of his dissent in Humphreys to highlight the absence of the award of interest in the later Indian depredations case before the Court of Claims, James Preston Beck, Administrator of Preston Beck, Jr:;

- the existence, for all but two of the first 50 numbered cases reported by the Court, of a Senate document that was identical in format to that used to convey the Letitia Humphreys findings to that chamber; and

- the declaration, within the Court's docket book, of "July 10 1856, reported to Congress" for the date that the findings in the Humphreys case were conveyed.

All these aspects suggest that the Court of Claims record of the Humphreys Florida claims proceedings should have been sent to the House of Representatives, perhaps under the case title of Letitia Humphreys, Administratrix of Andrew Atkinson, as Court of Claims Report 42.

\section{Acknowledgment}

We thank Francis Paul Prucha, S.J., for his constructive comments regarding this article.

\section{Notes and References}

1. An act to establish a court for the investigation of claims against the United States (1855). 10 Stat. 612. 
2. William A. Richardson, Chief Justice of the Court of Claims at the time of writing, stated that "[ $\mathrm{t}] \mathrm{o}$ neglect to hear petitioners, or not to act upon their complaints when heard, was practically the same to them as would be the effect of a law expressly abridging the right to petition in direct and flagrant violation of the Constitution" [History, Jurisdiction, and Practice of the Court of Claims, Washington, DC: Government Printing Office, 1885: p. 3].

3. Wiecek, William M. (1968). The origin of the United States Court of Claims. Administrative Law Review, 20, 387-406;

Cowen, Wilson, Nichols, Philip, \& Bennett, Marion T. (1978). The United States Court of Claims: A history: Part II. Origin-Development-Jurisdiction 1855-1978. Washington, DC: Committee on the Bicentennial of Independence and the Constitution of the Judicial Conference of the United States.

4. The Checklist of United States Public Documents, 1789-1909, Washington, DC: Government Printing Office, 1911, p. 1545 identifies Serial Set volumes 653, 654, and 655 as those that contain a "[d]igested summary and alphabetical list of private claims which have been presented to House of Representatives, 1st-31st Congress." There are over 2,100 pages of entries in these three volumes.

5. Richardson, History, Jurisdiction, and Practice of the Court of Claims, p. 4.

6. The first, and last, Court of Claims Reports in this early series are for Samuel P. Todd (34th Congress, 1st Session. Court of Claims Report 1, Serial Set 871, Washington, DC: Cornelius Wendell, 1856) and for William G. Brown (37th Congress, 3rd Session. Court of Claims Report 296, Serial Set 1173, Washington, DC: Government Printing Office, 1863). These were individual reports sent to the House of Representatives, and not part of the more familiar Court of Claims Reports. An Act in relation to the Court of Claims (1866: 14 Stat. 9) had specified that "a copy of the decisions" was to be furnished after each term of the Court, and the results of Court of Claims cases, from 1863 forward, began to appear in this public reporter. Richardson (History, Jurisdiction, and Practice of the Court of Claims: p. 16) noted that "Judge [Charles C.] Nott, in connection with the clerk, commenced in the year 1867 the regular publication of reports, under the title of 'Court of Claims Reports."'

7. The pertinent Serial Set volume numbers are 871, 872, 915, 970, 971, 972, 1021, 1072, 1073, 1074, 1075, 1076, 1108, 1109, 1110, 1146, 1147, and 1173 (Checklist of United States Public Documents: pp. 604-605).

8. Committee of Claims, to which was referred "An Act making appropriations for the payment of certain claims," together with opinions of the Court of Claims in the cases of Samuel P. Todd, John Shaw, and Isaac Beaugrand, have had the same under consideration, and report the said bill to the Senate, with the recommendation that the same do pass with an amendment, viz:. . ., 34th Congress, 1st session. Senate Report No. 49, Serial Set 836. (1857). Washington, DC: A.O.P. Nicholson.

9. Samuel P. Todd.

10. Isadore D. Beaugrand. (1856). 34th Congress, 1st Session. Court of Claims Report 2, Serial Set 871. Washington, DC: Cornelius Wendell.

11. John Shaw. (1856). 34th Congress, 1st Session. Court of Claims Report 3, Serial Set 871. Washington, DC: Cornelius Wendell. 
12. Samuel P. Todd, p. 12.

13. Isadore D. Beaugrand.

14. John Shaw.

15. Tables of and Annotated Index to the Congressional Series of United States Public Documents. Washington, DC: Government Printing Office, 1902: p. 253.

16. Checklist of United States Public Documents, p. 604.

17. CIS US Serial Set Index, Part 1: American State Papers and the 15th-34th Congresses, 1789-1857-Finding Lists (p. 2640). Washington, DC: Congressional Information Service.

18. Imholtz, August A. (2001). List of unused document and report numbers in the U.S. Congressional Serial Set, 1817-1969. DttP: Documents to the People, 29, 22.

19. See the product description at http://readex.com/scholarl/serlset.html. Almost every item with an identifying Serial Set volume number that is listed in this note was examined through this resource.

20. Thomas M. Newell. (1856). 34th Congress, 1st Session. Court of Claims Report 27, Serial Set 872. Washington, DC: Cornelius Wendell.

21. Isaac Swain. (1856). 34th Congress, 1st Session. Court of Claims Report 41, Serial Set 872. Washington, DC: Cornelius Wendell.

22. J. Boyd. (1857). 34th Congress, 3rd Session. Court of Claims Report 43, Serial Set 915. Washington, DC: Cornelius Wendell.

23. David Myerle. (1857). 34th Congress, 3rd Session. Court of Claims Report 81, Serial Set 915. Washington, DC: Cornelius Wendell.

24. Reports from the Court of Claims, Submitted to the House of Representatives During the Third Session of the Thirty-fourth Congress, 1856-'57. (1857). Serial Set 915. Washington, DC: Cornelius Wendell, p. iii.

25. An act to amend "An act to establish a court for the investigation of claims against the United States," approved February twenty-fourth, eighteen hundred and fifty-five. (1863). 12 Stat. 765.

26. Samuel P. Todd, p. 12.

27. Isaac Swain, p. 71.

28. J. Boyd, p. 8, emphasis added.

29. Huntington served as Chief Clerk between 1855 and 1873 (Cowen, Nichols, and Bennett, The United States Court of Claims: A History, p. 177).

30. Statement of the Reports of the Court of Claims. (1860). 36th Congress, 1st session. Senate Miscellaneous Document No. 4, Serial Set 1038. Washington, DC: George W. Bowman.

31. Letitia Humphreys, Adm'x vs. the United States. (1857). 35th Congress, 1st session. Senate Miscellaneous Document No. 105, Serial Set 935. Washington, DC: William A. Harris.

32. Ibid., p. 1, emphasis added.

33. See a brief biography of Blackford, Scarburgh, and Gilchrist in Marion T. Bennett. (1976). The United States Court of Claims: A History. Part I: The Judges: 1855-1976. Washington, DC: Committee on the Bicentennial of Independence and the Constitution of the Judicial Conference of the United States, pp. 4-8, 10-13, and xii and 1-3, respectively. 
34. Letitia Humphreys, Adm'x, p. 1.

35. Court of Claims, The Congressional Globe, 34th Congress, 1st session, 1 August 1856, p. 1876, emphasis added.

36. Mary Reeside. (1856). 34th Congress, 1st Session. Court of Claims Report 26, Serial Set 871. Washington, DC: Cornelius Wendell.

37. Treaty of Amity, Settlement, and Limits, Between the United States of America and His Catholic Majesty. (1819). 8 Stat. 252.

38. Treaty of Amity. 8 Stat. 252, 260.

39. Humphreys, Henry H. (1924). Andrew Atkinson Humphreys: A biography (pp. 1-24). Philadelphia, PA: John C. Winston Co.

40. "Invasion" appears to be the acknowledged term. An 1826 report by the Committee on Foreign Affairs used the phrase "invasion and occupation" to describe the events of 1812 (Inhabitants of the Province of East Florida, 19th Congress, 1st Session. House Report No. 112, Serial Set 141, Washington, DC: Gales and Seaton, 1826: p. 1). The specifications of this action may be seen in the 26 January 1811 letter from the Secretary of State, James Monroe, to General George Matthews and Colonel John McKee; the revocation of the General's authority in the 4 April 1812 letter from the Secretary; and in his letters of 10 April and 27 May 1812 transferring Matthew's duties to D.B. Mitchell, the Governor of Georgia (American State Papers: Foreign Relations: Vol. 3, Washington, DC: Gales and Seaton, 1832: pp. 571-573). A House Report - Inhabitants East Florida has a chronology of these events as well (22nd Congress, 1st Session. House Report No. 223, Serial Set 224, Washington, DC: Duff Green, 1832). Atkinson's son, Archibald, was killed during military action in August 1813, "while defending the rights of his adopted country against invaders from Georgia" (Humphreys, Andrew Atkinson Humphreys: A Biography, p. 7).

41. Letitia Humphreys, Adm'x, pp. 9-10. Mrs. Murphy's action was in response to the 1834 legislation entitled An Act for the relief of certain inhabitants of East Florida (6 Stat. 569). She was involved as well in an 1840 memorial presented to the Committee of Claims on behalf of her deceased husband, James Cashen, for losses sustained during the conflict (The Committee of Claims, to whom was referred the memorial of Susan Murphy, report... 26th Congress, 1st session. Senate Document No. 437, Serial Set 359, Washington, DC: Blair and Rives, 1840).

42. In an interesting parallel to the advisory responsibilities of the Court of Claims, Congress in 1823 authorized the superior courts in Saint Augustine and in Pensacola to adjudicate petitions based on the ninth Article of the treaty with Spain (An Act to carry into effect the ninth article of the treaty concluded between the United States and Spain, the twentysecond day of February, one thousand eight hundred and nineteen, 1823: 3 Stat. 768). In precisely the same manner as implemented for the Court of Claims, the superior court judge was instructed to provide to the Secretary of the Treasury a final assessment of the claim. The Secretary - as did Congress in response to the opinions of the Court of Claims determined the final awards, if any, for such treaty-related cases.

43. Letitia Humphreys, Adm'x, p. 7.

44. Ibid., p. 53. 
45. Ibid., p. 45.

46. Ibid., p. 7, emphasis original.

47. Robert Harrison and Others. (1855). 33rd Congress, 2nd session. House Report No. 33, Serial Set 808. Washington, DC: A.O.P. Nicholson.

48. Senate Committee on the Judiciary, The Committee on the Judiciary, to whom was referred the memorial of the legal representatives of John Forbes, deceased, ask leave to submit the following report ... (1851). 31st Congress, 2nd session. Senate Report No. 314, Serial Set 593. Washington, DC: Union Office.

49. Humphreys, under the name Humphries, had been before the United States Supreme Court herself as party to an appeal - United States vs. Heirs of Clarke (1842; 41 U.S. 228) brought by the United States against the Superior Court of East Florida's decision in favor of the heirs of George J. F. Clarke and George Atkinson in their claim to 15,000 acres of Florida land. The lower court's findings were affirmed. See a brief biography of Clarke in Louise Biles Hill, George J. F. Clarke, 1774-1836. (1943). Florida Historical Quarterly, $21,197-253$, and see the confirmation by the federal Commissioner of the General Land Office of a 1,000 acre Spanish land grant to Clarke in 1816 [Spanish claims-St. Augustine. Letter from the Secretary of the Treasury, transmitting a report of the Register and Receiver at St. Augustine, East Florida, upon certain Spanish claims. (1840). 26th Congress, 1st session. House Document No. 115, Serial Set 365. Washington, DC: Blair and Rives].

50. Letitia Humphreys, Adm'x, p. 58, emphasis added. The amounts under consideration were not small. In Humphreys, the Solicitor noted that "[t]his is one of a numerous and important class of claims known as the Florida claims, on which the sum of $\$ 1,200,000$ has already been paid, and the sum of $\$ 1,700,000$, or thereabouts, is still demanded from the United States for interest" (Letitia Humphreys, Adm'x, p. 73, emphasis added). See an analysis of this problem [Message from the President of the United States, in relation to the adjustment of the Florida claims, under the treaty of 1819. (1839). 25th Congress, 3rd session. Senate Document No. 97, Serial Set 339. Washington, DC: Blair and Rives]The Secretary of the Treasury, Levi Woodbury, reported that only $\$ 285,000$ had been distributed by January 1839.

51. Ibid., p. 68.

52. Ibid., p. 73-91. An Act to establish a court for the investigation of claims against the United States (10 Stat. 612) was legislated to create the Court of Claims and, in Section 2, to designate the Solicitor "to represent the government before said court." The 1868 act allowed appeals of Court decisions before the Supreme Court, but "the existing offices of solicitor, assistant solicitor, and deputy solicitor of the court of claims ... are hereby abolished from and after the first day of July, eighteen hundred and sixty-eight" (An Act to provide for appeals from the Court of Claims, and for other purposes. 15 Stat. 75). Blair served as Solicitor between 1855 and 1858.

53. Ibid., p. 99.

54. Ibid., p. 127. Scarburgh cited his dissent in Humphreys in a later Court of Claims Report, James Preston Beck, Administrator of Preston Beck, Jr. [37th Congress, 2nd session. (1861). Court of Claims Report 282, Serial Set 1146. Washington, DC: Government Printing Office]. In that petition - an Indian depredations case lasting 
twelve years - his explanation centered again upon the absence of the award of interest. He remarked (James Preston Beck, p. 54, emphasis added): "My opinion is that the words of this statute, according to their true intent and meaning, cannot be satisfied without giving to the claimant not only the value of the property taken at the time when it was taken, but also interest thereon. On this point I dissent from the opinion of the court (see opinion of Scarburgh, J., in Letitia Humphreys vs. The United States)."

55. David Myerle vs. the United States. (1857). 35th Congress, 1st session. Senate Miscellaneous Document No. 130, Serial Set 935. Washington, DC: William A. Harris.

56. Eliza Shaffer vs. the United States. (1857). 35th Congress, 1st session. Senate Miscellaneous Document No. 122, Serial Set 935. Washington, DC: William A. Harris.

57. David Myerle.

58. Eliza Shaffer, widow of Jonathan Shaffer. (1857). 35th Congress, 1st Session. Court of Claims Report 114, Serial Set 870. Washington, DC: Cornelius Wendell.

59. Miscellaneous Documents of the Senate of the United States. (1858). 35th Congress, 1st session, Serial Set 934. Washington, DC: William A Harris.

60. Journal of the Senate of the United States of America, 26 July 1854, 566.

61. Journal of the House of Representatives of the United States of America, 31 July 1854, 1238.

62. Journal of the House of Representatives of the United States of America, 26 January 1855, 246.

63. Andrew Atkinson, George Atkinson, George J. F. Clarke, and Robert Harrison had all made one or more land claims applications in the 1820s. See Land claims in Florida. (1834). American State Papers-Public Lands, Vol. 3 (pp. 725-863). Washington, DC: Gales and Seaton; Claims to lands in East and West Florida and Land claims in East Florida. (1859). American State Papers-Public Lands, Vol. 4 (pp. 155-426 and 561-748, respectively). Washington, DC: Gales and Seaton; Report and decisions upon private land claims in East Florida. (1860). American State Papers-Public Lands, Vol. 5 (pp. 402 430). Washington, DC: Gales and Seaton; Land claims in East Florida. (1860). American State Papers-Public Lands, Vol. 6 (pp. 55-121). Washington, DC: Gales and Seaton; and Number of Spanish claims to land depending in the Courts of Florida. (1861). American State Papers-Public Lands, Vol. 8 (pp. 247-296). Washington, DC: Gales and Seaton.

64. Journal of the Senate of the United States of America, 26 July 1854, p. 571, emphasis added. As a further indication of the delay that claimants faced, Letitia Humphreys on this date had just turned 68 years old; her father Andrew had died in 1825.

65. This is General Jurisdiction Case File 751, Robert Harrison and Others vs. the United States, of Record Group 123, Records of the United States Court of Claims.

66. Justice Blackford delivered the opinion of the Court, while Chief Justice Gilchrist furnished the Court's opinion on rehearing (Letitia Humphreys, Adm'x, pp. 91-129 and 159-167, respectively).

67. Robert Harrison. (1857). 35th Congress, 1st Session. Court of Claims Report 127, Serial Set 971. Washington, DC: James B. Steedman.

68. Robert Harrison vs. the United States. (1857). 34th Congress, 3rd session. Senate Miscellaneous Document No. 45, Serial Set 934. Washington, DC: William A Harris. 
69. The absent Senate reports are for the two cases of William W. Cox [34th Congress, 1st Session. Court of Claims Report 12, Serial Set 871. (1856). Washington, DC: Cornelius Wendell] and of Matthew G. Emery [34th Congress, 1st Session. Court of Claims Report 45, Serial Set 871. (1857). Washington, DC: Cornelius Wendell]. Cox was dated 16 May 1856, just as were 12 other of the first 50 Court of Claims Reports. The caption on this Report read: "Reported from the Court of Claims. Committed to a Committee of the Whole House, and ordered to be printed." Emery was one of the first three cases presented in 1857 on 19 January. Court of Claims Report 43, J. Boyd, was delivered on the same day as Emery.

70. Benjamin H. Springer. (1858). 35th Congress, 1st Session. Court of Claims Report 151, Serial Set 971. Washington, DC: James B. Steedman.

71. The Court's 1856 calendar was not found at the Court of Claims Library, or at the National Archives. We thank David Lockwood, Deputy Circuit Librarian at the United States Court of Appeals for the Federal Circuit, for his efforts in that search at the Court of Claims.

72. Senate Committee on Claims, The Committee on Claims, to whom were referred the reports of the Court of Claims in the cases of Letitia Humphreys, administratrix of Andrew Atkinson, deceased, and of Robert Harrison; and also the memorial of the said Harrison to Congress, praying, in behalf of himself and other claimants, the full and faithful execution of the 9th article of the treaty of 1819 with Spain, by the payment of the residue of the decrees made by the United States judges in their favor, report ... (1858). 35th Congress, 1st session. Senate Report No. 258, Serial Set 939. Washington, DC: William A. Harris; Senate Committee on Claims, The Committee on Claims, to whom were referred the cases of Letitia Humphreys and of Robert Harrison and other claimants, under the treaty of 1819 with Spain, together with voluminous documents in relation to said claims, have had the same under consideration, and, after a careful and patient reexamination of the whole subject, have reached the same conclusion at which this Committee arrived the first session of the last Congress, and adopt the report then made by this Committee through the honorable Mr. Clarke, of New Hampshire, then a member and nature of these claims, and which report is in the following words... (1860). 36th Congress, 1st session. Senate Report No. 93, Serial Set 1039. Washington, DC: George W. Bowman; Robert Harrison and Others. (1859). 35th Congress, 2nd session. House Report No. 216, Serial Set 1018. Washington, DC: James B. Steedman; and Robert Harrison and Others. (1874). 43rd Congress, 1st session. House Report No. 816, Serial Set 1627. Washington, DC: Government Printing Office. A later Senate Miscellaneous Document-List of private claims before the Senate of the United States from the commencement of the Fourteenth to the close of the Thirty-ninth Congress, prepared under the direction of the Secretary of the Senate, pursuant to the orders of the Senate of April 9, 1840; February 27, 1841; February 8, 1849; March 3, 1855; and March 16, 1866; and the act of July 20, 1868, making appropriations for sundry civil expenses of the government for the year ending June 30, 1869 [40th Congress, 3rd session. Senate Miscellaneous Document No. 43, Serial Set 1361. (1869). Washington, 
DC: Government Printing Office, p. 529]—Noted four entries for Letitia Humphreys. In the first three, she appears as an individual claimant and the notations indicate that the petition was brought before the Senate as a "Report from C.C; memorial" during the 34th Congress, 1st session; as a "Memorial" during the 3rd session of the same Congress; and as a "Report from C.C." during the 35th Congress, 1st session. This latter document is Senate Report No. 258 noted above. The last entry in this table identifies Humphreys as the administratrix for Andrew Atkinson, through a "Report of C. of Claims" that was conveyed as the mentioned Senate Report No. 93. The disposition of this claim is noted as "amended and postponed" (emphasis added), with the attendant remark that the Senate had "Ordered report Court of Claims be printed."

73. The Committee on Claims, 1860, p. 1.

74. Robert Harrison and Others, 1859, p. 3.

75. Robert Harrison vs. the United States, p. 6.

76. Robert Harrison and Others, 1874, p. 4.

77. Alexander M. Cumming. (1858). 35th Congress, 2nd Session. Court of Claims Report 180, Serial Set 1021. Washington, DC: James B. Steedman.

78. Alexander M. Cumming vs. the United States. (1858). 35th Congress, 2nd session. Senate Miscellaneous Document No. 6, Serial Set 993. Washington, DC: William A. Harris.

79. Ibid., p. 13, emphasis added.

80. State of Alabama. (1858). 35th Congress, 2nd Session. Court of Claims Report 181, Serial Set 1021. Washington, DC: James B. Steedman.

81. State of Alabama vs. the United States. (1858). 35th Congress, 2nd session. Senate Miscellaneous Document No. 8, Serial Set 993. Washington, DC: William A. Harris, p. 42. "Todd's case" was Court of Claims Report 1, Samuel P. Todd.

82. United States Court of Claims Digest, 1855 to Date: Vol. 1. (1950). St. Paul, MN: West Publishing, p. 440.

83. Devereux, John C. (1856). Court of Claims: Reports and digest of opinions delivered since the organization of the court. New York: Banks, Gould \& Co.

84. Ibid., pp. 204-215.

85. Ibid., p. 174. The remaining eight opinions, in Devereux's order but with their official Court of Claims case titles, are as follows: Samuel P. Todd (Court of Claims Report 1); Thomas H. Baird, Administrator (\#23); Robert Roberts (\#4); Susan Decatur (\#22); Mary Reeside (\#26); a first opinion for Sturges, Bennett and Co. that is contained within H. and F. W. Meyer (\#39); Estate of James Beatty (\#36); and a second opinion for Sturges, Bennet[t] and Co. (\#35). The first five documents are in Serial Set volume 871. The last three records are in volume 872. Both volumes were published in 1856 (Washington, DC: Cornelius Wendell).

86. Ibid.

87. Miscellaneous Documents of the Senate of the United States, p. 14.

88. State of Alabama vs. the United States.

89. Alexander M. Cumming vs. United States.

90. Robert Harrison.

91. Robert Harrison and Others, 1855, 1859, and 1874. 